\title{
ANALISIS PASAR WISATA SYARIAH DI KOTA YOGYAKARTA
}

\author{
Ade Ela Pratiwi, S. Par \\ Alumni Sekolah Tinggi Pariwisata AMPTA Yogyakarta \\ Email: keluargamuhtadi@gmail.com
}

\begin{abstract}
This article is the result of research that talks about how the development of the tourism market of sharia in the Yogyakarta City. Sharia travel is a new travel trend worldwide has excellent prospects for development and this concept into new ways to develop tourism in Yogyakarta to uphold the culture and values of Islam.

This study seeks to segment the tourism market in the Yogyakarta City and tourist developments seen from indicators sharia destination product and service quality, as well as merumukan attributes that are required in the development of sharia travel and recommends the development of a marketing strategy of sharia in the Yogyakarta City.

Descriptive method used to describe the facts about sharia travel market in the Yogyakarta City. The results show that tourists visiting Yogyakarta come from various parts of the archipelago, with demographic and psychographic diverse. Yogyakarta has a great potential to be developed as a tourist destination islamic views of destination product and service quality by adding the necessary attributes and by conducting massive marketing with promotional mix.
\end{abstract}

Keywords: Travel Sharia, Product Specials, Quality of Service, the Yogyakarta City

\section{PENDAHULUAN}

Pariwisata merupakan sebuah sektor yang telah mengambil peran penting dalam pembangunan perekonomian bangsabangsa di dunia. Kemajuan dan kesejahteraan yang semakin tinggi telah menjadikan pariwisata sebagai bagian pokok dari kebutuhan atau gaya hidup manusia, dan menggerakkan manusia untuk mengenal alam dan budaya di kawasankawasan negara lain. Sehingga secara tidak langsung, pergerakan manusia akan berpengaruh terhadap mata rantai ekonomi yang saling berkesinambungan menjadi industri jasa yang memberikan kontribusi bagi perekonomian dunia, perekonomian bangsa-bangsa, hingga peningkatan kesejahteraan ekonomi di tingkat masya-rakat lokal. Dunia pariwisata selalu mengalami peningkatan dan memunculkan sesuatu yang baru dalam perkembangannya.

Wisata syariah merupakan suatu tren baru dalam dunia pariwisata saat ini. Indonesia telah dikenal luas di dunia sebagai wisata halal terbaik di dunia atas kemenangannya dalam event "The World Halal Travel Summit \& Exhibition 2015". Indonesia berhasil mendapatkan tiga penghargaan sekaligus, meliputi; World Best Family Friendly Hotel, World Best Halal Honeymoon Destination dan World Best Halal Tourism Destination. Hal ini tentunya menjadi sebuah peluang besar yang memudahkan negara Indonesia untuk terus melakukan pengembangan wisata syariah dan industri jasa syariah, sehingga Indonesia dapat menanamkan bahwa Wisata Syariah identik dengan negara Indonesia di dalam mindset wisata dunia. 
Pada saat ini, wisatawan muslim telah meningkat secara cepat dibandingkan dengan tingkat global. Jumlah tingkat wisatawan muslim adalah 126 juta pada tahun 2011 dan diperkirakan akan mencapai 192 juta pada tahun 2020 (OnIslam, 2014).
Tabel dibawah ini menunjukan pertumbuhan muslim dari populasi dunia. Tabel 1 menunjukkan bahwa pengembangan wisata dan industri jasa syariah akan sangat berpeluang besar bagi negara Indonesia.

\section{Tabel 1 : Pertumbuhan Muslim Dari Populasi Dunia}

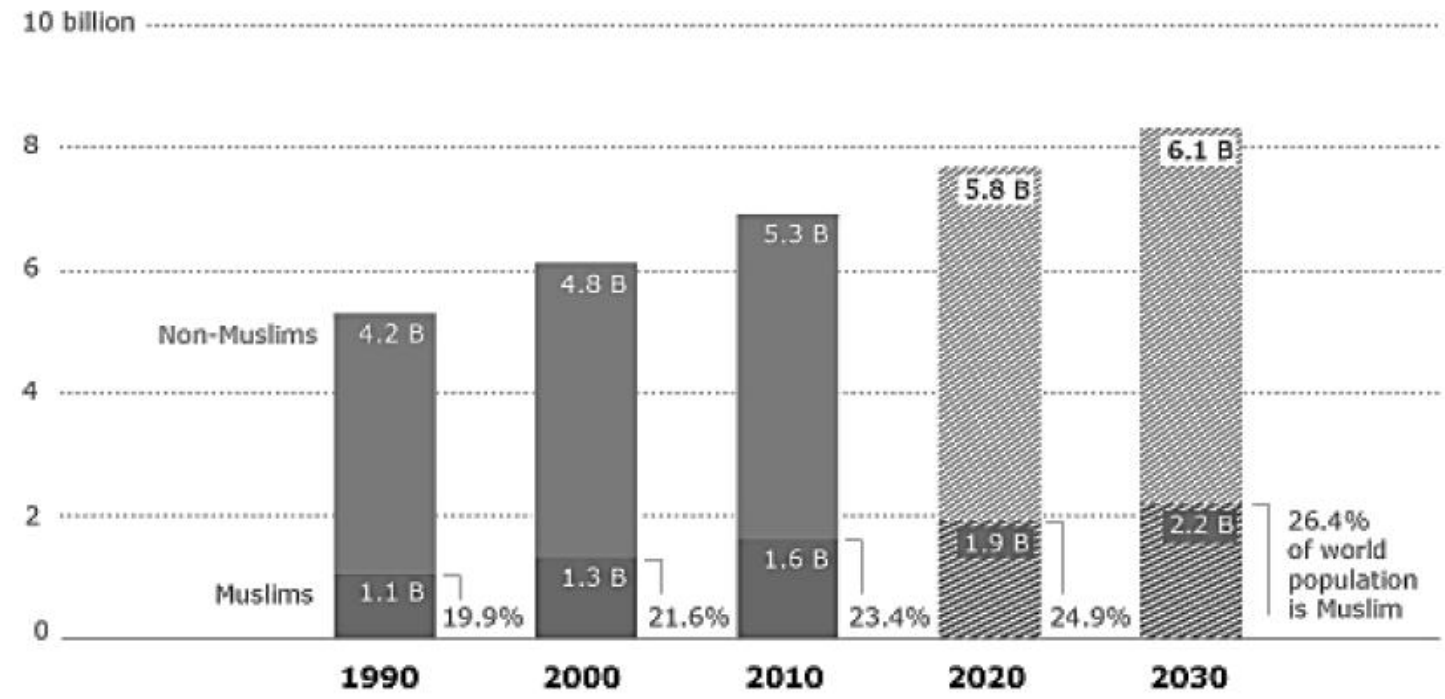

Sumber: Farahdel (2011) and PewResearchCenter (2011)

Indonesia juga merupakan salah satu Negara dengan penduduk yang mayoritas menganut agama Islam. Sebanyak 87,18\% dari total penduduk Indonesia beragama Islam dan sebanyak $12,9 \%$ dari total muslim di dunia, artinya jumlah muslim di Indonesia merupakan yang tertinggi dari negara-negara di dunia dengan jumlah mencapai 207 juta orang.

Kemenparekraf (2012) dalam Ariqa Nurwilda (2015) Jumlah wisatawan muslim mancanegara yang mengunjungi Indonesia melalui 19 pintu masuk ke Indonesia pada tahun 2012, Indonesia menerima wisatawan mancanegara sebanyak 8.044.462 wisatawan, dengan jumlah kunjungan wisatawan muslim mencapai 1.434 .041 orang atau $18,24 \%$ dari total jumlah wisatawan tahun 2012. 
Tabel 2 : Jumlah dan Persentase Penduduk Menurut Agama yang Dianut Tahun 2010

\begin{tabular}{lcc|}
\multicolumn{1}{c}{ Agama } & Jumlah Pemeluk (jiwa) & Persentase \\
\hline \multicolumn{1}{c}{$(1)$} & $(2)$ & $(3)$ \\
\hline Islam & 207176162 & 87,18 \\
\hline Kristen & 16528513 & 6,96 \\
\hline Katolik & 6907873 & 2,91 \\
\hline Hindu & 4012116 & 1,69 \\
\hline Budha & 1703254 & 0,72 \\
\hline Khong hu cu & 117091 & 0,05 \\
\hline Lainnya & 299617 & 0,13 \\
\hline Tidak Terjawab & 139582 & 0,06 \\
\hline Tidak Ditanyakan & 757118 & 0,32 \\
\hline Jumlah & 237641326 & 100 \\
\hline
\end{tabular}

Sumber : BPS Kewarganegaraan, Suku Bangsa, Agama, dan Bahasa Sehari-hari Penduduk Indonesia

Wisatawan Muslim terbanyak yang mengunjungi Indonesia menurut Direktorat Jendral Pariwisata Kemenparekraf (2012) yaitu Malaysia, sebanyak 684.952 wisatawan, kemudian Singapura dengan jumlah 189.445 wisatawan. Saudi Arabia juga cukup banyak dengan jumlah 84.046 wisatawan, India berjumlah 23.744 wisatawan serta Australia mencapai 15.456 wisatawan. Sehingga untuk menjalankan setiap kegiatan dengan landasan syariah Islam bukan hal yang sulit bagi masyarakat Indonesia. Karena disisi lain hal ini juga akan menjadi peluang yang sangat besar bagi para pengusaha barang maupun jasa untuk menjalankan bisnisnya sesuai dengan syariah islam, didukung dengan kekayaan alam dan budaya yang dimiliki Indonesia. Daerah Istimewa Yogyakarta merupakan salah satu wilayah yang strategis yang menjadi sasaran pengembangan wisata syariah oleh Mentri Pariwisata dan Ekonomi Kreatif Indonesia, dimana wilayah-wilayah sasaran pengembangan wisata syariah yang memiliki peluang besaradalah Aceh, Sumatera Barat, Riau,
Lampung, Banten, Jakarta, Jawa Barat, JawaTimur, Makassar dan Yogyakarta.

Di Daerah Istimewa Yogyakarta sendiri, khususnya Kota Yogyakarta terdapat fasilitas dan infastuktur yang dapat mendukung perkembangan wisata syariah, antaralain; terdapat beberapa hotel yang telah menggunakan konsep wisata syariah, restoran halal, bank dengan system syariah dan lainnya. Dalam penelitian Analisis Potensi Pariwisata Syariah dengan Mengoptimalkan Industri Kreatif di Jawa Tengah dan Yogyakarta (Haidar Tsany Alim, Andi Okta Riansyah, dkk.), dari segi konsep, $48 \%$ responden setuju dengan konsep pariwisata syariah. Dari segi kebutuhan, 68\% responden menekankan bahwa pariwisata syariah memiliki urgensi yang tinggi dalam pelaksanaannya.

Dari segi kesesuaian, 60\% responden setuju bahwa pariwisata syariah sesuai dengan kondisi masyarakat Indonesia. Berdasarkan hal tersebut, nilai yang sesuai dengan kebutuhan wisatawan adalah harapan atas kenyamanan dan ketenangan dalam berwisa tatanpa melupakan nilai- 
nilai keislamannya. Diyakini juga bahwa perkembangan wisata konsep syariah akan mengalami perkembangan peningkatan yang cukup signifikan, dikarenakan munculnya kesadaran masyarakat untuk kehalalan sebuah produk dan jasa. Sehingga akan mengurangi dampak negatif yang sering ditimbulkan secara social dengan adanya kegiatan wisata konvensional pada umumnya. Oleh karena masalah utama penelitian ini adalah bagaimana perkembangan pasarwisata syariah di Kota Yogyakarta. Untuk menjawab masalah ini peneliti berupaya (1) mengidentifikasi karateristik segmentasi pasar wisatadi Kota Yogyakarta, (2) menganalisis perkembangan wisata syariah dilihat dari indicator produk destinasi dan kualitas pelayanan menurut pandangan pasar wisata di Kota Yogyakarta (3) menetapkan atribut-atribut wisata syariah yang paling relevan, dan (4) merumuskan strategi pemasaran wisata syariah.

\section{LITERATUR REVIEW}

Din dalam Teoman dalam Ariqa (2015) mendefinisikan wisata syariah sebagai aktivitas wisata yang dilakukan oleh muslim yang memang didorong oleh motivasi untuk melakukan aktivitas Islam dan sesuai prinsip syariah. Sedangkan menurut Santi dan Sinta (2015: 133) wisata syariah adalah: "Sharia tourism is one of tourism systems which its implementation based on sharia rules. The main concept of sharia tourism is a recreational activities with Islamic value. The tourism carry sharia principles and not serving anything that is prohibited in the Islamic rules, like serving alcoholic drinks and a swimming pools without any restriction between male and female"
Negara-negara Muslim cenderung menafsirkan pariwisata berdasarkan apa yang Al-Qur'an katakan. Berikut bentuk pariwisata berdarkan Al-Qur'an:

1. Hijja (حجة) melibatkan perjalanan dan ziarah ke Mekah. Perjalanan ini merupakan persyaratan untuk setiap Muslim dewasa yang sehat. Setidaknya sekali dalam seumur hidup untuk mengambil haji.

2. Zejara (زيارة) mengacu pada kunjungan ke tempat-tempat suci lainnya.

3. Rihla (رحلة) adalah perjalanan untuk alasan lain, seperti pendidikan dan perdagangan.

Makna dasarnya adalah gerakan yang terarah, sebagai komponen dari perjalanan spiritual dalam pelayanan Tuhan. Shari'ah hukum menentukan apa yang dapat diterima-halal (حلال) dan apa yang tidak diterima-haram (حرام) dalam kehidupan sehari-hari dan selama perjalanan (Kovjanic, 2014). 


\section{Tabel 3 : Perbedaan Pariwisata Syariah dengan Pariwisata lainnya}

\begin{tabular}{|c|c|c|c|c|}
\hline No. & $\begin{array}{l}\text { Item } \\
\text { perbandingan }\end{array}$ & Konvensional & Religi & Syariah \\
\hline 1 & $\begin{array}{l}\text { Objek } \\
\text { kuliner }\end{array}$ & budaya, & $\begin{array}{l}\text { Tempat ibadah, } \\
\text { peninggalan } \\
\text { sejarah }\end{array}$ & Semuanya \\
\hline 2 & Tujuan & Menghibur & $\begin{array}{l}\text { Meningkatkan } \\
\text { spiritual }\end{array}$ & $\begin{array}{l}\text { Meningkatkan spirit religiusi- } \\
\text { tas dengan cara menghibur }\end{array}$ \\
\hline 3 & Target & $\begin{array}{lr}\text { Semata-mata } & \begin{array}{r}\text { hanya } \\
\text { hiburan }\end{array} \\
\text { untuk } & \text { nafsu } \\
\text { (memuaskan } & \text { dan } \\
\text { kesenangan } & \\
\text { kepuasan) } & \end{array}$ & $\begin{array}{l}\text { Aspek spiritual } \\
\text { yang bisa } \\
\text { menyenangkan } \\
\text { dan } \\
\text { menentramkan } \\
\text { jiwa }\end{array}$ & $\begin{array}{l}\text { Memenuhi keinginan dan } \\
\text { kesenangan, serta menumbuh- } \\
\text { kan kesadaran akan suatu } \\
\text { keyakinan hidup dan kelang- } \\
\text { sungan pribadi }\end{array}$ \\
\hline 4 & Guide & $\begin{array}{l}\text { Memahami dan } \\
\text { menguasai informasi } \\
\text { dan } \\
\text { menjelaskannya } \\
\text { semenarik mungkin }\end{array}$ & $\begin{array}{l}\text { Menguasaai } \\
\text { sejarah tokoh dan } \\
\text { lokasi yang } \\
\text { menjadi objek } \\
\text { wisata }\end{array}$ & $\begin{array}{l}\text { Membuat turis tertarik } \\
\text { terhadap objek sekaligus } \\
\text { membangkitkan spirit kesa- } \\
\text { daran hidup beretika, mampu } \\
\text { menjelaskan fungsi dan peran } \\
\text { syariah, dijelaskan semenarik } \\
\text { mungkin, sehingga wisatawan } \\
\text { paham apa peran syariah } \\
\text { dalam bentuk kebahagiaan dan } \\
\text { kepuasan batin }\end{array}$ \\
\hline 5 & $\begin{array}{l}\text { Fasilitas } \\
\text { ibadah }\end{array}$ & Sekedar pelengkap & $\begin{array}{l}\text { Termasuk dalam } \\
\text { Perjalanan }\end{array}$ & $\begin{array}{l}\text { Menjadi bagian yang menyatu } \\
\text { dengan objek pariwisata, ritual } \\
\text { ibadah menjadi paket hiburan }\end{array}$ \\
\hline 6 & Kuliner & Umum & Umum & $\begin{array}{l}\text { Spesifik yang halal unsur } \\
\text { haram tidak ada terkandung } \\
\text { dalam kulinernya) }\end{array}$ \\
\hline 7 & $\begin{array}{l}\text { Relasi } \\
\text { dengan } \\
\text { masyarakat }\end{array}$ & $\begin{array}{l}\text { Komplementer dan } \\
\text { semata-mata mengejar } \\
\text { keuntungan }\end{array}$ & $\begin{array}{l}\text { Komplementer } \\
\text { dan semata-mata } \\
\text { mengejar } \\
\text { keuntungan }\end{array}$ & $\begin{array}{l}\text { Integrated, berinteraksi. Beda- } \\
\text { sarkan prinsip syariah }\end{array}$ \\
\hline 8 & $\begin{array}{l}\text { Agenda } \\
\text { perjalanan }\end{array}$ & $\begin{array}{l}\text { Mengabaikan waktu, } \\
\text { semata-mata demi } \\
\text { mengejar keuntungan } \\
\text { (biasanya demi target } \\
\text { wisata bisa dirasakan } \\
\text { maksimal oleh } \\
\text { wisatawan) }\end{array}$ & $\begin{array}{l}\text { Komplementer, } \\
\text { demi mengejar } \\
\text { keuntungan }\end{array}$ & $\begin{array}{l}\text { Integrated, interaksi berdasar- } \\
\text { kan pada prinsip-prinsip sya- } \\
\text { riah }\end{array}$ \\
\hline
\end{tabular}

Sumber: Ngatawi Al zaztrow dalam Heri Sucipto\& Fitria Andayani (2014: 44)

Pada dasarnya wisata syariah adalah wisata yang dilakukan guna mengunjungi tempat-tempat wisata untuk melihat kebesaran ciptaan Allah yang ada di muka bumi, sehingga kita dapat belajar untuk lebih bersyukur dan memperbaiki kualitas iman pribadi dengan berpedoman pada kitab suci Al-Quran dan Al-Hadist.
Panduan Umum Wisata Syariah mengatur beberapa panduan dalam mengaplikasikan wisata syariah, yang meliputi destinasi, akomodasi, biro perjalanan wisata dan pramuwisata, usaha penerbangan dan juga tempat perbelanjaan dan persinggahan. Menurut Heri Sucipto 
dan Fitria Andayani (2014) adapun beberapa panduannya adalah:

1. Destinasi Wisata syariah

a. Destinasi wisata meliput wisata alam, wisata budaya, dan wisata buatan.

b. Tersedia fasilitas ibadah yang layak dan suci.

c. Tersedia makanan dan minuman yang halal.

d. Pertunjukan seni dan budaya serta atraksi yang tidak bertentangan dengan kriteria umum pariwisata syariah.

e. Terjaga kebersihan sanitasi dan lingkungan.

2. Akomodasi

a. Tersedia fasilitas yang layak untuk bersuci.

b. Tersedia fasilitas yang memudahkan untuk beribadah.

c. Tersedia makanan dan minuman halal.

d. Fasilitas dan suasana yang aman, nyaman, dan kondusif untuk keluarga dan bisnis.

e. Terjaga kebersihan sanitasi dan lingkungan.

3. Biro Perjalanan Wisata Syariah

a. Menyelenggarakan paket perjalanan atau wisata yang sesuai dengan kriteria umum pariwisata syariah.

b. Memiliki daftar akomodasi yang sesuai dengan panduan umum akomodasi pariwisata syariah.

c. Memiliki daftar usaha penyedia makanan dan minuman yang sesuai dengan panduan usaha penyedia makanan dan minuman pariwisata syariah.

4. Kriteria pramuwisata syariah: a. Memahami dan mampu melaksanakan nilai-nilai syariah dalam menjalankan tugas.

b. Berakhlak baik, komunikatif, ramah, jujur dan bertanggung jawab.

c. Berpenampilan sopan dan menarik sesuai dengan nilai dan etika islam.

d. Memiliki kompetensi kerja sesuai standar profesi yang berlaku.

5. Penerbangan Syariah

a. Menyediakan penerbangan ke sejumlah Negara islam.

b. Memberikan makanan halal selama perjalanan.

c. Memberikan pelayanan yang maksimal dan ramah sesuai dengan prinsip islam.

d. Para pramugari berpakaian sopan.

6. Pusat Perbelanjaan dan Tempat Persinggahan

a. Menyediakan masjid ataupun mushola yang layak.

b. Lokasi masjid tidak berada di tempat yang tersembunyi.

c. Menjaga kebersihan bangunan.

Penggunaan strategi pemasaran wisata syariah harus memastikan kesiapan produk yang akan dijual, karena memasarkan suatu produk yang belum siap dapat menjadikan masalah dan memunculkan persepsi yang buruk terhadap suatu produk wisata itu sendiri. Ali Hasan ( 2013) merekomendasikan sejumlah strategi pemasaran yang dapat digunakan misalnya saja setting strategy, market driven strategy, customer satisfaction, dan financial performance yang pada dasarnya untuk mendorong kegiatan pariwisata syariah itu sebagaimana kegiatan pariwisata pada umumnya, bauran produk, harga dan 
saluran informasi pariwisata harus dikomunikasikan kepada wisatawan melalui bauran promosi yang tersesedia seperti advertising, personal selling, sales promotion, public relations, direct marketing dan online marketing untuk membangun daya tarik produk wisata syariah bagi wisatawan. Selain itu, promosi yang dilakukan oleh wisatawan yang sudah berkunjung dan menikmati destinasi wisata (Word of Mouth) tetrtentu akan memiliki pengaruh yang lebih besar bagi calon wisatawan lainnya.

\section{METODE PENELITIAN}

Penelitian ini dilaksanakan di kawasan Kota Yogyakarta yaitu komplek Kepatihan sebagai area tourist spot merupakan yang area ramai dijadikan pilihan wisatawan untuk beristirahat dan berkumpul. Penelitian ini dilaksanakan dari 15 Febuari 2016 sampai dengan 15 Maret 2016. Sampel penilitian ini adalah 100 responden yang diambil secara purposive Sampling, dan data dikumpulkan dengan kuesioner dan dianalisis dengan metode deskriptif kuantitatif.

\section{HASIL PENELITIAN DAN PEMBAHASAN}

Dari penelitian yang telah dilakukan dengan jumlah total responden 100 wisatawan yang berkunjung di Kota Yogyakarta hasil dapat dijelaskan sebagai berikut :

\section{Persepsi Wisatawan Terhadap Wisata Syariah}

\section{Tabel 4 : Hasil Analisis Deskriptip}

\begin{tabular}{|c|c|c|c|c|c|c|c|c|c|c|c|c|}
\hline Kategori & PWS & Kategori & KPS & KRH & KTB & HKS & FDM & KPKS & PMK & EMPH & KKS & PSD \\
\hline $\begin{array}{l}\text { Sangat } \\
\text { Tidak } \\
\text { Paham }\end{array}$ & $36 \%$ & $\begin{array}{l}\text { Tidak } \\
\text { Setuju }\end{array}$ & $10 \%$ & $2 \%$ & $1 \%$ & $8 \%$ & $4 \%$ & $5 \%$ & $3 \%$ & $3 \%$ & - & $1 \%$ \\
\hline $\begin{array}{l}\text { Sedikit } \\
\text { Paham }\end{array}$ & $35 \%$ & Setuju & $64 \%$ & $44 \%$ & $39 \%$ & $64 \%$ & $52 \%$ & $63 \%$ & $65 \%$ & $64 \%$ & $59 \%$ & $66 \%$ \\
\hline $\begin{array}{l}\text { Cukup } \\
\text { Paham }\end{array}$ & $25 \%$ & $\begin{array}{l}\text { Sangat } \\
\text { Setuju }\end{array}$ & $25 \%$ & $54 \%$ & $60 \%$ & $28 \%$ & $44 \%$ & $30 \%$ & $30 \%$ & $31 \%$ & $39 \%$ & $29 \%$ \\
\hline $\begin{array}{l}\text { Sangat } \\
\text { Paham }\end{array}$ & $3 \%$ & Total & 99 & 100 & 100 & 100 & 100 & 98 & 98 & 98 & 98 & 96 \\
\hline Total & 99 & $\begin{array}{l}\text { Missing } \\
\text { System }\end{array}$ & $1 \%$ & - & - & - & - & $2 \%$ & $2 \%$ & $2 \%$ & $2 \%$ & $4 \%$ \\
\hline $\begin{array}{l}\text { Missing } \\
\text { System }\end{array}$ & 1 & Total & 100 & - & - & - & - & 100 & 100 & 100 & 100 & 100 \\
\hline Total & 100 & & & & & & & & & & & \\
\hline
\end{tabular}

Keterangan:

$\begin{aligned} & \text { PWS }= \text { Pemahaman terhadap Wisata } \\ & \text { Syariah } \\ & \text { LD = } \text { Lokasi Destinasi } \\ & \text { KPS = } \text { Ketersediaan Penginapan Syariah } \\ & \text { KRH = } \text { Ketersediaan Restoran Halal } \\ & \text { KTB = } \text { Ketersediaan Tempat Beribadah } \\ & \text { HKS = Hiburan dengan Konsep Syariah }\end{aligned}$

FDM = Fasilitas Destinasi yang Memadahi

KPKS = Kualitas Pelayanan dengan Konsep Syariah

PMK = Pelayanan Menangani Komplain

$\mathrm{EMPH}=$ Emphaty

KKS = Keramahan dan Kesopanan Staf

PSD = Pengetahuan Staf yang baik tentang Destinasi 
Tabel 1 di atas menunjukkan bahwa

a. terdapat $3 \%$ dari jumlah total reponden yang sangat memahami tentang apa itu konsep wisata syariah, sedangkan $36 \%$ responden merasa sangat tidak paham mengenai konsep wisata syariah, sehingga mereka sama sekali tidak mengerti bagaimana sebenarnya konsep wisata syariah. Setelah itu terdapat 35\% responden yang merasa sedikit paham, yang berarti responden sedikit mengetahui konsep wisata syariah, dimana bagi mereka pastinya wisata syariah adalah wisata yang berhubungan dengan etika dan peraturan Islam. Sisanya $25 \%$ responden yang cukup memahami konsep wisata syariah, dalam hal ini respondenmasih belum dapat membedakan antara wisata syariah, religi dan ziarah, namun mereka sudah mengerti bagaimana alur wisata syariah secara garis besar.Terdapat 1 missing data dikarenakan adanya satu orang responden yang tidak mengisi data.

b. 6 tempat yang menjadi tourist spot area atau objek wisata di Kota Yogyakarta dengan jumlah total responden 100 orang, didapat data yang menunjukan bahwa $6 \%$ responden merasa bahwa letak objek wisata di Kota Yogyakarta tidak strategis, $23 \%$ wisatawan sangat setuju dengan letak objek wisata yang strategis, dan sebagian besar responden dengan prosentase $70 \%$ dari total responden setuju dengan letak objek wisata di Kota Yogyakarta yang strategis.Terdapat $1 \%$ missing data dikarenakan adanya data yang tidak diisi oleh responden.

c. $10 \%$ dari jumlah total responden beranggapan tidak setuju dengan sudah adanya ketersediaan penginapan syariah di Kota Yogyakarta, sementara $64 \%$ responden setuju dengan sudah adanya ketersediaan penginapan syariah yang di Kota Yogyakarta. Sisanya terdapat $25 \%$ responden yang sangat setuju dengan adanya ketersediaan penginapan syariah yang sudah ada di Kota Yogyakarta.Terdapat $1 \%$ missing data dikarenakan adanya satu orang responden yang tidak mengisi data.

d. $2 \%$ dari jumlah total responden yang tidak setuju dengan adanya ketersediaan restoran halal di Kota Yogyakarta, hal ini dapat disebabkan dengan masih adanya restoranrestoran yang menyediakan minuman beralkohol atau masakan yang tidak halal, sedangkan $44 \%$ responden setuju dengan adanya ketersediaan restoran halal yang ada di Kota Yogyakarta, serta sebagian besar responden dengan prosentase $54 \%$ menyatakan sangat setuju dengan ketersediaan restoran halal yang sudah memenuhi kebutuhan wisatawan di Kota Yogyakarta.

e. Tempat ibadah dapat berupa masjid, mushola ataupun suatu ruangan yang dikhususkan untuk kegiatan ibadah, dengan disediakan perlengakapnnya berupa mukena, sajadah, dan juga AlQur'an. 60\% responden menyatakan sangat setuju dengan ketersediaan tempat ibadah yang memenuhi kebutuhan wisatawan di Kota Yogyakarta, 39\% responden menyatakan setuju dengan ketersediaan tempat ibadah yang sudah ada, dan hanya $1 \%$ responden yang menyatakan tidak setuju dengan sudah adanya ketersediaan tempat 
ibadah guna memenuhi kebutuhan wisatawan di Kota Yogyakarta.

f. $8 \%$ responden menyatakan ketidaksetujuannya dengan ketersediaan hiburan yang sesuai dengan konsep wisata syariah di Kota Yogyakarta, sedangkan sebagian besar wisatawan dengan prosentase $64 \%$ responden menyatakan setuju dengan sudah terpenuhinya ketersedian hiburan yang sesuai dengan konsep syariah di Kota Yogyakarta. Selain itu terdapat $28 \%$ responden menyatakan sangat setuju dengan sudah adanya pemenuhan kebutuhan wisatawan akan hiburan yang sesuai dengan konsep syariah.

g. ketersediaan fasilitas yang memadahi di setiap destinasi, dapat dilihat dari hasil tabel yang ada di atas bahwa hanya $4 \%$ responden menyatakan tidak setuju dengan sudah terpenuhinya ketersedian fasilitas yang memadahi, 52\% responden menyata-kan setuju dengan pemenuhan fasilitas yang memadahi yang sudah tersedia di setiap destinsi dan terdapat $44 \%$ responden yang menyatakan sangat setuju dengansudah terpenuhi-nya fsilitas yang memadahi bagi wisatawan.

h. 5\% responden menyatakan tidak setuju dengan adanya pelayanan yang telah dilakukan oleh para pelaku wisata yang sudah sesuai dengan konsep syariah, hal ini dikarenakan masih terdapat kebingungan bagi wisatawan mengenai bagaimana pelayanan dengan konsep syariah itu seharusnya diterapkan. Terdapat $63 \%$ responden menyatakan setuju dengan sudah adanya pelayanan sesuai dengan syariah islam, selanjutnya $30 \%$ responden menyatakan sangat setuju dengan hal tersebut. Sisa $2 \%$ wisatawan tidak memberikan pendapat mereka, hal ini dikarenakan responden merasa benar-benar tidak mengetahui akan hal tersebut.

i. $3 \%$ responden menyatakan ketidaksetujuannya terhadap penanganan komplain yang sudah dilakukan dengan baik, hal ini dapat dikarenakan adanya kekecewaan wisatawan secara pribadi terhadap pelayanan yang telah diberikan sehingga merasa kecewa. Sebagian besar responden dengan prosentasi $65 \%$ menyatakan setuju dengan pelayanan komplain dengan baik, dan terdapat $30 \%$ responden yang menyatakan sangat setuju, hal ini dikarenakan mereka merasa sangat puas dengan pelayanan yang telah diberikan.Terdapat $2 \%$ missing data dikarenakan adanya responden yang tidak mengisi data tersebut.Hal ini menunjukkan bahwa pelayanan yang diberikan Kota Yogyakarta kepada wisatawan sudah dapat dikatakan bagus dan memenuhi kebutuhan wisatawan.

j. 6 titik tempat wisata yang banyak dikunjung oleh wisatawan,dimana sebelumnya mereka sudah melakukan perjalanan wisata di tempat-tempat lain yang ada di Kota Yogyakarta maupun sekitarnya. Dapat dilihat hasilnya bahwa $3 \%$ reponden menyatakan tidak setuju dengan adanya kesediaan staf destinasi untuk membantu wisatawan yang mengalami kesulitan, 64\% responden menyatakan setuju dengan adanya kesediaan staf destinasi untuk membantu dan $31 \%$ menyatakan sangat setuju dengan sudah adanya kesediaan staf destinasi untuk 
membantu, selain itu terdapat $2 \%$ missing data dikarenakan adanya reponden yang tidak mengisi.

k. 59\% responden menyatakan setuju dengan kesopanan dan keramahan staf destinasi yang telah dilakukan dengan baik, dan $39 \%$ responden menyatakan sangat setuju dengan pelayanan di Kota Yogyakarta yang dilakukan dengan sopan dan penuh keramahan.

1. hanya $1 \%$ responden menyatakan bahwa tidak setuju dengan sudah adanya pengetahuan yang baik mengenai suatu destinasi dari staf destinasi yang ada. Terdapat $66 \%$ responden menyatakan setuju dengan sudah adanya pengetahuan yang baik mengenai suatu destinasi dari staf dan $29 \%$ responden menyatakan sangat setuju dengan hal tersebut.Sehingga dari hasil penelitian ini menunjukkan bahwa sudah terpenuhinya kebutuhan wisatawan akan informasi di suatu destinasi.terdapat 4\% missing data karena adanya responden yang tidak mengisi.

\section{Pemahaman Dinas Kebudayaan dan Pariwisata Kota Yogyakarta}

Wawancara yang dilakukan dengan pihak Dinas Kebudayaan dan Pariwisata Kota Yogyakarta (diwakili oleh Nurwin) dari bagian promosi wisata menunjukkan sesuatu hal yang mungkin akan dilakukan, karena pada saat ini pihak pemerintah belum melakukan pengembangan wisata syariah secara khusus. Wisata syariah juga masih menjadi hal yang asing didengar oleh pihak Dinas itu sendiri. Sehingga diperlukan kajian yang lebih mendalam mengenai konsep wisata syariah. 


\section{Tabel 5 : Hasil Wawancara dengan Dinas Pariwisata Kota Yogyakarta}

\begin{tabular}{|c|c|c|}
\hline No & Daftar Pertanyaan & Jawaban \\
\hline 1 & $\begin{array}{l}\text { Apakah menurut Bpk/Ibu, Yogyakarta } \\
\text { memiliki potensi untuk dikembangkan } \\
\text { sebagai destinasi syariah? }\end{array}$ & $\begin{array}{l}\text { Ya. Yogyakarta sangat berpotensi untuk } \\
\text { dikembangkan sebagai wisata syariah di Indonesia. }\end{array}$ \\
\hline 2 & $\begin{array}{l}\text { Sejauh mana langkah pengembangan wisata } \\
\text { syariah di Yogyakarta? }\end{array}$ & $\begin{array}{l}\text { Pada saat ini, belum ada konsen untuk pengembangan } \\
\text { wisata syariah, namun hal itu menjadi sebuah rencana } \\
\text { untuk direalisasikan suatu saat nanti. Hal ini dika- } \\
\text { renakan secara aturan formal mengenai wisata syariah } \\
\text { belum ada. }\end{array}$ \\
\hline 3 & $\begin{array}{l}\text { Apakah fasilitas yang sudah ada di } \\
\text { Yogyakarta sudah memenuhi guna } \\
\text { pengembangan wisata syariah? }\end{array}$ & $\begin{array}{l}\text { Jika untuk fasilitas-fasilitas umum di setiap destinasi } \\
\text { sepertinya sudah. Hanya perlu ditambahi agar lebih } \\
\text { baik lagi. }\end{array}$ \\
\hline 4 & $\begin{array}{l}\text { Bagaimana upaya pemerintah dalam } \\
\text { memberikan sosialisasi kepada masyarakat } \\
\text { mengenai pemahaman wisata syariah? }\end{array}$ & $\begin{array}{l}\text { Dikarenakan saat ini belum ada tindakan dalam } \\
\text { pengembangan wisata syariah, maka dari pemerintah } \\
\text { belum ada sosialisasi mengenai hal tersebut. }\end{array}$ \\
\hline 5 & $\begin{array}{l}\text { Adakah target pasar utama yang menjadi } \\
\text { sasaran pemerintah Yogyakarta dalam } \\
\text { pengembangan wisata syariah? }\end{array}$ & $\begin{array}{l}\text { Mengenai target pasar, pemerintah tidak membuat } \\
\text { suatu sasaran khusus, karena pemasaran dilakukan } \\
\text { secara merata, dan semua wilayah bisa menjadi target } \\
\text { pasar yang merata. }\end{array}$ \\
\hline 6 & $\begin{array}{l}\text { Menurut Bpk/Ibu, manasajakah destinasi } \\
\text { wisata yang menjadi sasaran utama, yang } \\
\text { berpotensi besar untuk dikembangkan } \\
\text { sebagai destinasi wisata syariah? }\end{array}$ & $\begin{array}{l}\text { Masjid gede, keraton dan sekitarnya, tempat } \\
\text { peninggalan sejarah islam, serta kota gede. }\end{array}$ \\
\hline 7 & $\begin{array}{l}\text { Adakah upaya perbaikan produk destinasi, } \\
\text { pelayanan dan promosi wisata dalam } \\
\text { pengembangan wisata syariah di Yogyakarta } \\
?\end{array}$ & $\begin{array}{l}\text { Mungkin untuk hal ini pemerintah akan melakukan } \\
\text { pengembangan SDM dan prasarana (pelengkap) untuk } \\
\text { pengembangan wisata syariah. } \\
\text { Yang menjadi masalah hingga saat ini adalah } \\
\text { kemacetan lalu lintas dan juga area parkir yang belum } \\
\text { memadahi, dan seringkali penuh. Namun soal } \\
\text { pelayanan, Yogyakarta menurut saya sudah siap. }\end{array}$ \\
\hline 8 & $\begin{array}{l}\text { Bagaimana upaya pemerintah dalam } \\
\text { mengatasi heterogenitas wisatawan (dalam } \\
\text { hal agama) untuk penerapan konsep wisata } \\
\text { syariah di Yogyakarta? }\end{array}$ & $\begin{array}{l}\text { Sebenarnya pemerintah tidak memiliki aturan atau } \\
\text { kebijakan khusus untuk megatasi hal itu, karena sudah } \\
\text { tentunya jika aktivitas wisata pastilah sangat bersifat } \\
\text { heterogenitas, namun mungkin jika dalam hal agama } \\
\text { pemerintah dapat melakukan upaya, misalnya dalam } \\
\text { hal kuliner, yang mana pemerintah membantu tentang } \\
\text { pengecekan halal atau tidaknya produk yang dapat } \\
\text { dikonsumsi oleh konsumen. }\end{array}$ \\
\hline 9 & $\begin{array}{l}\text { Apakah pemerintah Yogyakarta pernah } \\
\text { melakukan studi mengenai wisata syariah } \\
\text { sebelumnya? } \\
\text { Jika sudah, bagaimana hasilnya? }\end{array}$ & Sejauh ini belum ada studi mengenai wisata syariah. \\
\hline 10 & $\begin{array}{l}\text { Bagaimana prospek wisata syariah di } \\
\text { Yogyakarta menurut Bpk/Ibu ? }\end{array}$ & $\begin{array}{l}\text { Prospek wisata syariah tentunya sangat bagus, } \\
\text { ditambah dengan kekayaan potensi wisata yang ada di } \\
\text { Yogyakarta, baik berupa alam maupun budaya. Seperti } \\
\text { contoh; keraton yang memiliki sejarah yang dapat } \\
\text { dijadikan destinasi wisata syariah, dengan menon- } \\
\text { jolkan sisi sejarah keislaman keraton. }\end{array}$ \\
\hline 11 & $\begin{array}{l}\text { Adakah cara pemasaran khusus yang akan } \\
\text { dilakukan oleh pemerintah dalam pengem- } \\
\text { bangan wisata syariah di Yogyakarta? }\end{array}$ & $\begin{array}{l}\text { Dalam hal pemasaran, mungkin tidak jauh berbeda } \\
\text { dengan pemasaran destinasi wisata pada umumnya, } \\
\text { yaitu dengan media social, media cetak, pameran } \\
\text { (fisik/non fisik), table top (suatu pertemuan yang } \\
\text { dilakukan pihak Dinas dengan calon pembeli secara } \\
\text { langsung), sehingga pembeli dapat melakukan } \\
\text { penawaran secara langsung, dan transaksi berlangsung } \\
\text { pada saat itu juga. }\end{array}$ \\
\hline
\end{tabular}


Dari hasil wawancara dengan pihak Dinas Pariwisata Kota Yogyakarta, dapat disimpulkan bahwa saat ini baik pihak pemerintah maupun pihak swasta sebenarnya belum benar-benar memahami tentang apa itu konsep wisata syariah. Namun, pemerintah sangat yakin bahwa Kota Yogyakarta memiliki potensi yang sangat baik untuk melakukan pengembangan wisata syariah. Sehingga walaupun saat ini belum ada langkah pengembangan mengenai wisata syariah, hal itu dapat menjadi rencana yang baik untuk pengembangan wisata Kota Yogyakarta kedepan.

Dalam wawancara ini terdapat beberapa jawaban yang menggunakan kata "mungkin", dikarenakan memang belum ada langkah pengembangan secara nyata. Pihak pemerintah berpendapat bahwa mereka benar-benar harus melakukan persiapan yang matang dalam hal ini, dikarenakan suatu hal baru yang tidak digaraap dengan sungguh-sungguh dan belum siap, maka akan mengalami kegagalan dalam pemasarannya.

Jika dilihat untuk kondisi aktivitas wisata saat ini di Kota Yogyakarta, sebenarnya Kota Yogyakarta sudah sedikit banyak menerapkan konsep wisata syariah, anatara lain; konsep toilet yang dipisah antara laki-laki dan perempuan, tidak ada penjualan alkohol di setiap destinasi atau penginapan (kecuali hotel berbintang yang sudah mendapatkan ijin), terdapat lembaga yang bertugas khusus untuk mengecek halal atau tidaknya suatu produk yang dikonsumsi. Pemerintah meyakini adanya prospek yang baik dalam pengembangan wisata syariah, ditambah banyaknya wisatawan yang mayoritas beragama islam di Indonesia.

\section{Travel Agent (PT Trendz Cahaya} Abadi Tour \& Travel)

Tabel 6 adalah hasil wawancara dengan salah satu usaha jasa wisata biro perjalanan di Kota Yogyakarta, Edwin Ismedi Himna CEO PT Trendz Cahaya Abadi Tour \& Travel menilai bahwa Kota Yogyakarta memiliki potensi yang baik, ditambah dengan kekayaan culture yang dimiliki. Lebih lanjut CEO PT Trendz Cahaya Abadi Tour \& Travel menjelaskan bahwa masyarakat sudah mengetahui mengenai perkembangan wisata syariah dikarenakan hal ini sudah menjadi program pemerintah. Di sisi lain Nurwin sebagai wakil dari Dinas menyatakan konsep wisata syaraiah masih terdengar asing bagi masyarakat atau wisatawan awam. Jika dibandingkan dengan hasil penelitian 100 wisatawan, menunjukan bahwa $36 \%$ menyatakan sangat tidak paham dan $35 \%$ menyatakan sedikit paham mengenai konsep wisata syariah. 


\section{Tabel 6 : Hasil Wawancara dengan PT Trendz Cahaya Abadi Tour \& Travel}

\begin{tabular}{|c|c|c|}
\hline No. & Pertanyaan & Jawaban \\
\hline 1. & $\begin{array}{l}\text { Apakah menurut Bpk/Ibu, Yogyakarta } \\
\text { memiliki potensi untuk dikembang- } \\
\text { kan sebagai destinasi syariah? }\end{array}$ & $\begin{array}{l}\text { Potensi yang ada di Yogyakarta sangat baik dan } \\
\text { mendukung, ditambah dengan adanya cultureyang } \\
\text { dimiliki oleh Yogyakarta. }\end{array}$ \\
\hline 2. & $\begin{array}{l}\text { Apakah fasilitas yang sudah ada di } \\
\text { Yogyakarta sudah memenuhi guna } \\
\text { pengembangan wisata syariah? }\end{array}$ & $\begin{array}{l}\text { Fasilitas-fasilitas yang ada di Kota Yogyakarta ini } \\
\text { sudah memenuhi. }\end{array}$ \\
\hline 3. & $\begin{array}{l}\text { Menurut Bpk/Ibu sudahkah penge- } \\
\text { tahuan wisata syariah ini diketahui } \\
\text { oleh kalangan masyarakat umum? }\end{array}$ & $\begin{array}{l}\text { Menurut saya sudah, karena sebenarnya hal ini } \\
\text { sudah menjadi program pemerintah. }\end{array}$ \\
\hline 4. & $\begin{array}{l}\text { Menurut Bpk/Ibu, manasajakah } \\
\text { destinasi wisata yang menjadi sasaran } \\
\text { utama, yang berpotensi besar untuk } \\
\text { dikembangkan sebagai destinasi } \\
\text { wisata syariah? }\end{array}$ & $\begin{array}{l}\text { Menurut saya destinasi yang berpotensi adalah } \\
\text { masjid-masjid kuno, Kota Gede, dan daerah-daerah } \\
\text { yang banyak memiliki kantong pondok pesantren. }\end{array}$ \\
\hline 5. & $\begin{array}{l}\text { Sudah adakah produk wisata berupa } \\
\text { paket wisata syariah di Trand Tour? }\end{array}$ & $\begin{array}{l}\text { Untuk sementara ini belum ada paket wisata } \\
\text { syariah resmi, namun jika terdapat permintaan dari } \\
\text { konsumen maka akan dibuatkan. }\end{array}$ \\
\hline 6. & $\begin{array}{l}\text { Bagaimana prospek wisata syariah di } \\
\text { Yogyakarta menurut Bpk/Ibu? }\end{array}$ & $\begin{array}{l}\text { Prospek wisata syariah ini sangat menjajikan, jika } \\
\text { pemerintah serius dalam melakukan pengembang- } \\
\text { an ini, maka kedepannya pasti akan berpeluang } \\
\text { sangat besar. }\end{array}$ \\
\hline 7. & $\begin{array}{l}\text { Sudah adakah study atau survey yang } \\
\text { dilakukan pihak Trand Tour dalam } \\
\text { upaya pengadaan paket wisata syariah } \\
\text { ? }\end{array}$ & $\begin{array}{l}\text { Untuk survey belum ada, namun ada prospek jika } \\
\text { wisata syariah sudah digarap dengan baik dan } \\
\text { memiliki produk. }\end{array}$ \\
\hline 8. & $\begin{array}{l}\text { Menurut Bpk/Ibu, adakah pemasaran } \\
\text { khusus dalam pemasaran produk } \\
\text { wisata syariah? }\end{array}$ & $\begin{array}{l}\text { Tentunya pemasarannya hampir mirip dengan } \\
\text { wisata pada umumnya, namun judul dalam } \\
\text { pemasaran wisata syariah harusnya berbeda dengan } \\
\text { pemasaran wisata pada umumnya. Judul yang } \\
\text { digunakan harus memiliki komitmen sesuai dengan } \\
\text { syariah. Dalam aplikasinya bisa menggunakan } \\
\text { web, media social dan media lain yang biasa } \\
\text { digunakan }\end{array}$ \\
\hline 9. & $\begin{array}{l}\text { Adakah target pasar wisata utama } \\
\text { dalam pemasaran wisata syariah? }\end{array}$ & $\begin{array}{l}\text { Untuk target pasar utama, yang pasti adalah } \\
\text { Malaysia, Brunai Darusalam, dan juga Singapura } \\
\text { yang memiliki penduduk dengan mayoritas mus- } \\
\text { lim. }\end{array}$ \\
\hline 10. & $\begin{array}{l}\text { Adakah saran untuk perbaikan produk } \\
\text { destinasi, kualitas pelayanan dan juga } \\
\text { promosi dalam pengembangan wisata } \\
\text { syariah? }\end{array}$ & $\begin{array}{l}\text { Jika memang pemerintah benar-benar serius dalam } \\
\text { melakukan pengembangan wisata syariah, maka } \\
\text { sebaiknya lebih mempersiapkan infrastuktur yang } \\
\text { berbau syariah, misalnya; hotel, restoran, dan } \\
\text { fasilitas lainnya. } \\
\text { Destinasi yang dipilih juga benar-benar harus } \\
\text { memenuhi konsep wisata syariah dan mendapatkan } \\
\text { dukungan dari pemerintah dan masyarakat. } \\
\text { Untuk promosinya, lebih dapat disebarkan melalui } \\
\text { web atau social media. }\end{array}$ \\
\hline
\end{tabular}

Di tengah perkembangan wisata prospek tren wisata baru ini sangat syariah, sebagai pelaku bisnis biro berpeluang besar jika ada keseriusan dari perjalanan swasta, Edwin menilai bahwa pemerintah dalam melakukan pengem- 
bangan. Selain itu, beliau juga mencoba untuk mulai membuat produk (paket wisata) syariah yang dapat ditawarkan oleh para wisatawan walaupun belum dibuat secara resmi, jadi hanya menunggu jika ada request dari wisatawan. Menurut Edwin tentunya pemasaran wisata syariah dan wisata pada umumnya adalah sama, namun judul dalam pemasaran wisata syariah harusnya berbeda dengan pemasaran wisata pada umumnya. Judul yang digunakan harus memiliki komitmen sesuai dengan syariah islam, sehingga image yang diciptakan juga benar-benar menunjukan suasana destinasi wisata dengan konsep syariah yang sesungguhnya.

Sebagai salah satu pelaku wisata dengan usaha jasa biro perjalanan wisata yang berlokasi di Kota Yogyakarta, sudah terdapat beberapa destinasi wisata syariah yang menurutnya dapat digarap menjadi destinasi wisata syariah, antara lain; Masjid Agung, Masjid Kauman, Masjid Kotagedhe, pesntren-pesantren hingga beberapa panti asuhan yang ada di Kota Yogyakarta.

Konsep wisata syariah di Indonesia dianggap masih belum menemukan kemantapan, sehingga masih banyak kebingungan yang dialami para pelaku bisnis wisata dalam melakukan penerapan konsep syariah yang sesungguhnya.Hal ini karena belum adanya regulasi yang resmi yang mengatur bagaimana konsep wisata syariah itu harus berjalan. Sehingga menurut Bapak Edwin jika memang pemerintah serius dalam melakukan pengembangan wisata syariah, maka sebaiknya lebih mempersiapkan infrastuktur yang berbau syariah, misalnya; hotel, restoran, dan fasilitas lainnya, destinasi yang dipilih juga benar-benar harus memenuhi konsep wisata syariah dan mendapatkan dukungan dari pemerintah dan masyarakat, serta promosi dapat dilakukan secara masif melalui berbagai media untuk mengenalkan pada dunia bahwa Kota Yogyakarta memiliki produk wisata syariah.

\section{Atribut-Atribut Wisata Syariah di Kota Yogyakarta}

Banyak pihak yang menilai bahwa munculnya wisata syariah memberikan peluang yang besar bagi Indonesia untuk mengembangkan wisata syariah dengan menjunjung tinggi budaya dan nilai-nilai islami yang dimiliki Negara Indonesia. Pemerintah melalui Kementrian Pariwisata dan Ekonomi Kreatif (Kemen-parekraf) merumuskan pengembangan pariwisata syariah meliputi empat jenis komponen usaha pariwisata yaitu perhotelan, restoran, biro perjalanan, atau jasa perjalanan wisata, dan spa. Selain itu, sarana penunjang pariwisata lainnya juga akan diikutsertakan.

Dengan adanya penetapan komponenkomponen usaha pariwisata guna mengembangkan wisata syariah, tentunya pemerin-tah dan stake holder pariwisata lainnya haruslah melakukan langkah awal dalam pengembangannya, salah satu langkah terpenting dalam pengembangan wisata syariah adalah penentuan produk dan daerah tujuan wisata syariah, yang meliputi objek wisata, amenitas, dan atraksi yang sesuai dengan nilai-nilai islami. Penetapan daerah tujuan wisata syariah sebaiknya juga tetap memperhatiakan kesiapan sumber daya manusia, kultur masyarakat setempat, produk-produk wisata daerah, dan akomodasi wisata.

Pariwisata syariah bukan hanya meliputi keberadaan tempat wisata ziarah dan religi tetapi juga mencakup ketersediaan fasilitas pendukung laiinya. Sedangkan Kota Yogyakarta dalam hal ini sudah memiliki beberapa hal yang dibutuhkan wisatawan dalam melakukan perjalanan 
wisata syariah, antara lain seperti restoran halal, tersedianya tempat beribadah dan adanya jasa akomodasi syariah. Tabel 7 menunjukkan atribut-atribut lain yang masih diperlukan Kota Yogyakarta untuk mengembangkan wisata syariah dengan konsep yang lebih matang

Dalam pengembangan wisata syariah, Negara Indonesia masih menemukan kesulitan dalam hal regulasi untuk menentukan konsep wisata syariah terkait dengan standarisasi pelayanan syariah. Sehingga akan menjadikan kesulitan tersediri juga bagi Kota Yogyakarta dalam melakukan pengembangan wisata syariah. Standarisasi pelayanan syariah menjadi hal yang sangat penting di suatu destinasi wisata untuk menunjukan kesungguhan dalam pengembangan wisata syariah. Namun untuk usaha jasa hotel syariah telah diatur dalam Peraturan Menteri Pariwisata dan Ekonomi Kreatif Republik Indonesia Nomor 2 Tahun 2014 Tentang Pedoman Penyelenggaraan Usaha Hotel Syariah.

\section{KESIMPULAN DAN REKOMENDASI}

\section{Kesimpulan}

\section{1) Indikator Produk Destinasi}

Dari hasil penelitian 36\% responden merasa sangat tidak paham mengenai konsep wisata syariah, sehingga mereka sama sekali tidak mengerti bagaimana sebenarnya konsep wisata syariah. Setelah itu terdapat 35\% responden yang merasa sedikit paham, yang berarti responden sedikit mengetahui konsep wisata syariah, dimana bagi mereka pastinya wisata syariah adalah wisata yang berhubungan dengan etika dan peraturan Islam. Sebagian besar responden dengan prosentase $70 \%$ dari total responden setuju dengan letak objek wisata di Kota Yogyakarta yang strategis. Sementara $64 \%$ responden setuju dengan sudah adanya ketersediaan penginapan syariah di Kota Yogyakarta, serta sebagian besar responden dengan prosentase 54\% menyatakan sangat setuju dengan ketersediaan restoran halal yang sudah memenuhi kebutuhan wisatawan di Kota Yogyakarta. 
Tabel 7 : Jenis-Jenis Atribut Wisata Syariah

\begin{tabular}{|c|c|c|c|}
\hline Fasilitas Ibadah & Produk Halal & Moral ke-Islaman & $\begin{array}{c}\text { Tidak Terdapat } \\
\text { Alkohol dan } \\
\text { Aktivitas Perjudian }\end{array}$ \\
\hline $\begin{array}{l}\text { Ketersediaan masjid } \\
\text { atau mushola di setiap } \\
\text { destinasi dan tempat } \\
\text { umum. }\end{array}$ & $\begin{array}{l}\text { Ketersediaan makanan } \\
\text { halal di setiap destinasi, } \\
\text { bandara, tempat } \\
\text { perbelanjaan, hotel, } \\
\text { restoran dan tempat } \\
\text { umum lainnya. }\end{array}$ & $\begin{array}{l}\text { Diberlakukannya } \\
\text { pakaian sragam yang } \\
\text { sesuai syariah islam } \\
\text { bagi setiap staf hotel } \\
\text { atau restoran. }\end{array}$ & $\begin{array}{l}\text { Melarang adanya } \\
\text { minuman alcohol } \\
\text { yang dijual secara } \\
\text { bebas di setiap } \\
\text { destinasi, retoran, } \\
\text { hotel maupun tem- } \\
\text { pat umum. }\end{array}$ \\
\hline $\begin{array}{l}\text { Adanya kumandang } \\
\text { adzan di setiap waktu } \\
\text { jadwal sholat. }\end{array}$ & $\begin{array}{l}\text { Tersedia dapur halal } \\
\text { yang khusus di setiap } \\
\text { hotel dan restoran. }\end{array}$ & $\begin{array}{l}\text { Kesadaran masyarakat } \\
\text { untuk mengenakan } \\
\text { pakaian yang sesuai } \\
\text { syariah islam bagi } \\
\text { yang beragama islam } \\
\text { di tempat-tempat } \\
\text { umum. }\end{array}$ & $\begin{array}{l}\text { Melarang adanya } \\
\text { aktivitas perjudian } \\
\text { di suatu destinasi, } \\
\text { hotel, maupun } \\
\text { tempat-tempat } \\
\text { umum lainnya. }\end{array}$ \\
\hline $\begin{array}{l}\text { Adanya petunjuk arah } \\
\text { kiblat. }\end{array}$ & $\begin{array}{l}\text { Tersedia area khusus } \\
\text { wanita di hotel atau di } \\
\text { suatu destinasi. }\end{array}$ & $\begin{array}{l}\text { Melarang adanya } \\
\text { kegiatan prostiusi }\end{array}$ & $\begin{array}{l}\text { Merancaang } \\
\text { aktivitas Islamic } \\
\text { Tourism Events }\end{array}$ \\
\hline $\begin{array}{l}\text { Tersedianya Al-Qur'an } \\
\text { di setiap ruang kamar } \\
\text { di hotel. }\end{array}$ & $\begin{array}{l}\text { Tersedia kolam renang } \\
\text { dan area olahraga yang } \\
\text { terpisah antara laki-laki } \\
\text { dan perempuan. }\end{array}$ & $\begin{array}{l}\text { Melarang adanya } \\
\text { kegiatan sex di tempat } \\
\text { umum. }\end{array}$ & \\
\hline $\begin{array}{l}\text { Tersedia suplai air di } \\
\text { toilet baik di setiap } \\
\text { destinasi, bandara, } \\
\text { tempat perbelanjaan, } \\
\text { hotel, dan tempat } \\
\text { umum lainnya. }\end{array}$ & $\begin{array}{l}\text { Tidak menyediakan } \\
\text { saluran sex pada system } \\
\text { hiburan di hotel. }\end{array}$ & $\begin{array}{l}\text { Adanya penyensoran } \\
\text { tayangan bagi orang } \\
\text { dewasa di acara TV. }\end{array}$ & \\
\hline
\end{tabular}

Terdapat $60 \%$ responden menyatakan sangat setuju dengan ketersediaan tempat ibadah yang memenuhi kebutuhan wisatawan di Kota Yogyakarta. Sebagian besar wisatawan dengan prosentase $64 \%$ responden menyatakan setuju dengan sudah terpenuhinya ketersedian hiburan yang sesuai dengan konsep syariah di Kota Yogyakarta. Setelah itu terdapat 52\% responden menyatakan setuju dengan pemenuhan fasilitas yang memadahi yang sudah tersedia di setiap destinasi bagi wisatawan.

\section{2) Indikator Kualitas Pelayanan.}

Terdapat $63 \%$ responden menyatakan setuju dengan sudah adanya pelayanan sesuai dengan syariah islam, prosentase dengan jumlah $65 \%$ reponden menyatakan setuju dengan adanya pelayanan menangani komplain dengan baik. Sementara 64\% responden menyatakan setuju dengan adanya kesediaan staf destinasi untuk membantu saat wisatawan mengalami kebingungan atau kesulitan saat berkunjung 
ke destinasi. Dari hasil penelitian menunjukkan bahwa 59\% responden menyatakan setuju dengan adanya kesopanan dan keramahan staf destinasi yang telah dilakukan dengan baik. Terdapat $66 \%$ responden menyatakan setuju dengan sudah adanya pengetahuan yang baik mengenai suatu destinasi dari staf. Sehingga dari hasil penelitian ini menunju-kkan bahwa sudah terpenuhinya kepuasan wisatawan saat berwisata dan kebutuhan wisatawan akan informasi di suatu destinasi.

\section{3) Atribut-Atribut Wisata Syariah yang Diperlukan}

Jika dilihat untuk kondisi aktivitas wisata saat ini di Kota Yogyakarta, sebenarnya Kota Yogyakarta sudah sedikit banyak menerapkan konsep wisata syariah, anatara lain; konsep toilet yang dipisah antara laki-laki dan perempuan, tidak ada penjualan alkohol di setiap destinasi atau penginapan (kecuali hotel berbintang yang sudah mendapatkan ijin), terdapat lembaga yang bertugas khusus untuk mengecek halal atau tidaknya suatu produk yang dikonsumsi.

Pemerintah meyakini adanya prospek yang baik dalam pengembangan wisata syariah, ditambah banyaknya wisatawan yang mayoritas beragama muslim di Indonesia. Sehingga menurut Bapak Edwin jika memang pemerintah serius dalam melakukan pengembangan wisata syariah, maka sebaiknya lebih mempersiapkan infrastuktur yang berbau syariah, misalnya; hotel, restoran, dan fasilitas lainnya, destinasi yang dipilih juga benar-benar harus memenuhi konsep wisata syariah dan mendapatkan dukungan dari pemerintah dan masyarakat, serta promosi dapat dilakukan secara masif melalui berbagai media untuk mengenalkan pada dunia bahwa Kota Yogyakarta memiliki produk wisata syariah. Sedangkan Kota Yogyakarta dalam hal ini sudah memiliki beberapa hal yang dibutuhkan wisatawan dalam melakukan perjalanan wisata syariah, antara lain seperti restoran halal, tersedianya tempat beribadah dan adanya jasa akomodasi syariah.

\section{Rekomendasi}

Penelitian ini memberikan informasi mengenai perkembangan analisis wisata syariah dilihat dari indikator produk destinasi dan kualitas pelayanan di Kota Yogyakarta. Berdasarkan kesimpulan di atas, maka saran yang diusulkan peneliti adalah sebagai berikut:

\section{1) Strategi Pemasaran Wisata Syariah.}

Dalam menentukan strategi pemasaran sebaiknya didasari dulu kesiapan produk wisata syariah dalam memenuhi kebutuhan dan keinginan wisatawan. Dilanjutkan dengan mengem-bangkan nilai-nilai yang jelas bagi setiap segmen pasar, sehingga hal ini dapat meningkatkan daya tarik bagi wisatawan untuk datang dan membeli produk dan jasa wisata syariah yang ada di Kota Yogyakarta.

Pemanfaatan teknologi dan media yang semakin berkembang dapat mempermudah untuk melakukan kegiatan promosi berupa periklanan (advertising) tanpa harus banyak mengeluarkan biaya. Promosi produk wisata melalui media social, web dan situ internet lainnya tentu bukan lagi menjadi hal yang baru bagi pelaku wisata pada saat ini. Dengan mengadakan pertemuan langsung dengan pembeli dan melakukan penawaran secara langsung, sehingga pihak penawar akan mengerti dengan benar apa yang dinginkan oleh pembeli produk. Sehingga dengan adanya aktifitas promosi berupa personal selling dapat menjadikan 
alat yang cukup efektif untuk membangun preferensi wisatawan.

Wisata syariah memang masih terdengar asing bagi wisatawan umum, namun jika promosi penjualan ini dilakukan dengan maksimal, maka setidaknya pelaku bisnis wisata dapat membuka jalan untuk mengenalkan pada wisatawan, baik nusantara maupun mancanegara, bahwa Kota Yogyakarta memiliki produk wisata syariah yang layak untuk dikunjungi. Hubungan masyarakat merupakan hal yang penting untuk dilakukan dalam aktifitas pemasaran guna mempermudah wisatawan/ konsumen mengenal produk wisata yang dijual. Aktifitas public relation dapat dilakukan dengan kerjasama antar pelaku wisata atau stakeholder guna mengem-bangkan produk wisata syariah.

Selain itu, dengan adanya interaksi secara aktif melalui promosi penjualan, maka pemasaran dapat berifat fleksibel sesuai dengan tanggapan calon pembeli/ wisatawan yang ingin menikmati produk wisata syariah di Kota Yogyakarta. Kegiatan pemasaran ini juga dapat memanfaatkan perkembangan media elektronik atau internet yang sudah ada. Sehingga dalam kegiatan online pemasaran, pelaku bisnis wisata tidak harus memikirkan adanya keterbatasan waktu, karena hal ini dapat diakses oleh calon pembeli atau wisatawan selama 24 jam. Terlebih lagi kegiatan pemasaran ini dapat menjangkau pada lingkup pasar yang lebih luas, bukan hanya pasar wisatawan nusantara, namun juga sampai mancanegara. Kegiatan pemasaran online juga memberikan keuntungan dengan adanya pengurangan biaya promosi yang berlebih, sehingga pemasaran online dapat memberikan nilai lebih dalam menghadapi persaingan.

\section{2) Pemerintah Kota Yogyakarta}

Perbaikan dan penambahan atributatribut wisata syariah guna mengembangkan wisata syariah di Kota Yogyakarta harus diperhatikan, sehingga Kota Yogyakarta siap untuk menerima wisatawan dengan tujuan untuk melakukan perjalanan wisata syariah. Pengelolaan dan pengembangan potensi wisata syariah harus lebih digali dan dikaji, sehingga produk wisata syariah di Kota Yogyakarta mampu bersaing dengan produk wisata syariah wilayah-wilayah lain yang sudah mulai mengembangkan konsep wisata tersebut.

\section{3) Pelaku bisnis wisata di Kota Yogyakarta,}

Pelaku usaha wisata sebaiknya lebih bersemangat untuk memasarkan paketpaket wisata syariah dengan produk destinasi yang sudah ada di Kota Yogyakarta yang sudah layak untuk dikunjungi sebagai destinasi wisata syariah. Tidak lupa dengan memperhatikan susunan atau jadwal paket wisata yang dijual dengan mengutamakan unsur-unsur syariah di dalamnya. Sedangkan untuk pelaku usaha akomodasi, sebaiknya dapat melakukan pemasaran secara masif, sehingga keberadaan hotel/penginapan syariah dapat diakses oleh wisatawan yang membutuhkan. Penambahan dan perbaikan fasilitas juga harus menjadi rencana kedepan, guna memenuhi kebutuhan dan keinginan wisatawan yang melakukan perjalanan wisata syariah. Semua pelaku bisnis pariwisata, baik swasta maupun pemerintah, sebaiknya melakukan sosiali-sasi kepada masyarakat atau wisatawan umum mengenai wisata syariah. Jika dilihat dari hasil penelitian diperoleh data yaitu $36 \%$ wisatawan sangat tidak paham mengenai konsep wisata syariah, dan $35 \%$ wisatawan menyatakan sedikit paham mengenai 
konsep wisata syariah. Dikarenakan pengembangan wisata syariah ini sudah menjadi sebuah program pemerintah, maka diharapkan pemerintah dan semua pelaku bisnis wisata membuktikan keseriusan dalam melakukan pengembangan, terutama dalam memberikan pemahaman tentang apa itu wisata syariah kepada masyarakat/ wisatawan umum.

\section{4) Riset lanjutan}

Penelitian lanjutan diharapkan dapat mengembangkan penelitian ini dengan memperluas ruang lingkup penelitian dan mampu melakukan penelitian lebih mendalam mengenai perkembangan wisata syariah di wilayah Yogyakarta. Selain itu peneliti selanjutnya diharapkan dapat menambahkan indikator yang akan diteliti, dengan harapan dapat menghasilkan temuan baru yang lebih bermanfaat bagi para praktisi, terutama yang bergerak di bidang pariwisata.

\section{DAFTAR PUSTAKA}

Ali, Fahruddin Sabri. 2010. "Perkembangan Hotel Syari'ah Di Indonesia; Mengonsep Pariwisata Islami”.Vol. XVIII.

Battour, Mohamed dan Mohd Nazari Ismail. 2014. "The Role of Destination Attributes in Islamic Tourism". EDP Sciences.

Farahdel, F. 2011. "Islamic attributes and its Impact on Muslim Tourists Satifaction: A study of Iran". Master Dessertation, Graduate School of Bussiness, University of Malay, 198

Hamdan, Fathi. 2015. Skripsi "Analisis Ekspektasi Masyarakat Terhadap Pengembangan Pariwisata Di
Kabupaten Gunung Kidul (Studi Kasus Masyarakat Kawasan Wisata Goa Pindul)". Yogyakarta: STP AMPTA Yogyakarta.

Hasan, Ali. 2013. "Marketing dan Kasus Kasus Pilihan". Yogyakarta: CAPS (Center for Academic Publishing Service)

Jonet, Nikasius. 2011. "Modul. Analisis Daya Tarik Wisata". Yogyakarta: STP AMPTA Yogyakarta.

Lestari, Siti Rokhmi dan Eva Dwi Kurniawan. 2011. "Bahasa Indonesia untuk Perguruan Tinggi”. Yogyakarta: Edukasi Pustaka.

Khalilur, Muhammad Rahman. 2014. "Motivating factors of Islamic Tourist's Destination Loyalty: An Empirical Investigation in Malaysia". Jurnal of Tourism and Hospitality Management. Vol. 2. 63 $-77$

Kovjanic, G. 2014." Islamic Tourism as a Factor of the Middle East. Turizam", 18 (1), 33-43.

M. Kesrul. 2003. "Penyelenggaraan Operasi Perjalanan Wisata". Jakarta: PT.Grasindo.

Mutiara, Santi Asih., and Sinta Kemala Asih . 2015. "Marketing Strategy Implementation in Developing Sharia Tourism in Indonesia". Vol. 84; pp:133-137

Nurwilda, Ariqa Sugiarti. 2015. "Strategi Pengembangan Pariwisata Syariah Untuk Meningkatkan Kunjungan Wisatawan Muslim Domestik Dan Mancanegara Di Kota Bandung". Perpustakaan Upi.edu

Pew Reaserch Center. 2011. "The Future of 
the Global Muslim Population": Projections for 2010-2030. 1615 L St., NW, Suite 700: Pew Reaserch Center's Forum on Religion \& Public Life.

Salamun, Salasiah. 2015. Skripsi "Tingkat Kesiapan Mahasiswa Semester Akhir STP AMPTA dalam Menghadapi MEA". Yogyakarta: STP AMPTA Yogyakarta.

Santoso, Agus Djoko. 2015. "Perancangan Penelitian Ilmiah". Yogyakarta: LP2M STP AMPTA Yogyakarta

Sanusi, Anwar. 2011. "Metodologi Penelitian Bisnis". Jakarta: Salemba Empat.

Sucipto, Hery dan Fitria Andayani. 2014. "Wisata Syariah. Karakter, Potensi, Prospek \& Tantangannya". Jakarta Selatan: Grafindo Books Media \& Wisata Syariah Consulting.

Tsany, Haidar Alim., Andi Okta Riansyah, dkk., "Analisis Potensi Pariwisata Syariah Dengan Mengoptimalkan Industri Kreatif Di Jawa Tengah Dan Yogyakarta" 